\title{
The Impact of Audit Quality on Earnings Predictability
}

\section{Khaled Hussainey}

Address for correspondence:

Dr. Khaled Hussainey

Division of Accounting \& Finance,

Stirling Management School,

University of Stirling

Stirling FK9 4LA

United Kingdom

Email: khaled.hussainey@ stir.ac.uk 


\begin{abstract}
Purpose - This paper examines the impact of audit quality, measured by financial statements audited by the big four accounting firms, on the investors' ability to predict future earnings for profitable and unprofitable firms.
\end{abstract}

Methodology - The paper uses the returns-earnings regression model developed by Collins et al. (1994) and the author interacts all independent variables in this model with a dummy variable, AUDIT, which is set to equal one if financial statements audited by the big four accounting firms, zero otherwise. Future Earnings Response Coefficient (FERC) is the measure of earnings predictability.

Findings - The paper finds that investors are able to better anticipate future earnings when financial statements are audited by the big four accounting firms. However, the findings are not applicable for unprofitable firms.

Practical implications - The findings of the paper have implications for auditing related academic research and the users of financial statements. In particular, the study shows that the big four accounting firms have not lost their audit quality advantage and that financial statements audited by the big four accounting firms are arguably of higher quality than those audited by non-big four accounting firms.

Originality/value - To the best of the author's knowledge, there is no UK study to date examining the association of the quality of financial statements audited by the big four accounting firms and the returns-earnings association. Consequently, this paper significantly contributes to the limited literature on the perceived value relevance of audit quality.

Keywords: Quality of financial statement; Returns-earnings association; Audit quality; Earnings response coefficient; Mandatory disclosure; Earnings predictability.

Classification: Research paper 


\section{Introduction}

Accounting earnings information has attracted interest in prior accounting and finance literature since the publication of two key research papers by Ball and Brown (1968) and Beaver (1968). As explained in Walker (2004), the literature emerges as a response by accounting and finance academics to the market efficiency hypothesis, which is concerned with the degree to which stock prices fully reflect all available information. Since accounting is an important source of value relevant information about companies, it is natural for academic researchers to examine the efficiency of the stock market with respect to accounting information (Walker, 2004).

In a review article, Lev (1989) surveys academic papers on the association between current stock returns and current earnings changes. He finds that the R-Square values obtained by regressing current year stock returns on annual earnings or earnings changes are very low. He also finds that the values of earnings response coefficient (ERC) estimates are very low. He attributes these weak results to the low accounting earnings quality. Lev's review paper has motivated academic researchers to identify other potential explanations for the weak returns-earnings association. A possible explanation for low earnings quality is the lack of timeliness in reported accounting earnings (Collins et al, 1994). The literature on accounting earnings' timeliness is concerned with the degree to which the stock market has access to value-relevant information other than reported accounting earnings. Reported accounting earnings' lack of timeliness is due to the fact that value-relevant events are reflected in stock prices as soon as the information reaches the stock market, while their influence on reported earnings often occurs with a time lag (Schleicher, 1996). This lagged reaction of earnings is to a certain extent due to accounting conventions such as 
objectivity, conservatism and verifiability that prevent earnings from reflecting the value-relevant information on a timely basis (Schleicher, 1996). Collins et al. (1994) significantly contribute to the accounting and finance literature by empirically investigating the reasons for the weak returns-earnings association. They show that earnings' lack of timeliness is the most important contributing factor to the low returns-earnings relation. They produce a new model to improve the association between returns and earnings known as the Future Earnings Response Coefficient "FERC" framework. The development by Collins et al. (1994) of a reliable measure of the association between stock returns and accounting earnings makes it possible to examine the consequences of audit quality on the predictability of earnings change. Therefore, Collins et al (1994) is used in the present study as a measure of earnings predictability.

In a recent paper, Lee et al (2007) investigate whether the impact of the quality of financial statements, measured by the ability of investors to anticipate future earnings, is higher when financial statements are audited by the big accounting firms. They examine the association between current year stock returns and future earnings for big and small accounting firms. They find that investors are able to better anticipate future earnings when financial statements are audited by the big accounting firms. However, the authors did not find significant results in the more recent years of their sample (years from 1996 to 2001). So they conclude that the big accounting firms lost their audit quality advantage from 1996.

The present paper contributes to the literature in two crucial issues. First, it examines the association between quality of financial statements and share price anticipation of 
earnings for UK firms. This helps to examine the extent to which the big accounting firms lost (or still have) their audit quality advantage in the UK. Second, it tests the degree to which the associations between the quality of financial statements and share price anticipation of earnings differ between profitable and unprofitable firms.

The paper is organised as follows. The next section reviews prior literature and develops the research hypotheses and the methodology is then described. The data is then described and results discussed, followed by the conclusion and areas for future research

\section{Literature review and research hypotheses}

Earnings predictability is related to the degree to which investors can predict future earnings change of a firm (or a group of firms). Financial statements are designed to provide value-relevant information for investors (and other users). Investors are using accounting information to study the current performance of a particular firm of interest and then to predict its future prospects. Therefore, high quality disclosure should enable investors and financial analysts to better anticipate a firm's future prospects.

A number of definitions of 'disclosure quality' are given in the literature. For example, Diamond and Verrecchia (1991) define disclosure quality as the accuracy of investors' beliefs about stock prices following the disclosure. King (1996) defines

disclosure quality as the degree of self-interested bias in corporate disclosure. 
Hopkins (1996) defines disclosure quality as the extent to which current and potential investors can read and interpret the information easily. ${ }^{1}$

Measuring investors' perception of the firm's disclosure quality is not an easy task. Hence, different proxies are used in the literature. In a more recent survey of the literature, Healy and Palepu (2001) review academic papers that consider different proxies for the quality of corporate disclosures. They categorise these proxies into three groups: management forecasts, subjective ratings and self-constructed indices. Other studies use computer software packages to automate the generation of the disclosure scores for a large sample of firms (Hussainey et al, 2003).

Recently, considerable attention has been given to examining the association between disclosure quality and the stock market's ability to anticipate future earnings (e.g. Schleicher and Walker, 1999; Lundholm and Myers, 2002; Gelb and Zarowin, 2002; Hussainey et al., 2003; Schleicher et al., 2007 and Hussainey and Walker, 2009). These papers find that the stock market's ability to anticipate future annual earnings changes is significantly improved when the firm provides higher levels of disclosure. However, these studies did not take into account audit quality as a potential variable signalling value relevant information for investors when valuing firms' future prospects.

In the auditing literature, audit quality is defined in terms of the accuracy of information supplied by the auditor to investors (Titman and Trueman, 1986); or the auditors' ability to detect and eliminate misstatements and manipulations in financial

\footnotetext{
${ }^{1}$ All these definitions are cited in Beattie et al. (2001) and explained in Hussainey (2004).
} 
statements (Palmrose, 1988; Davidson and Neu, 1993). For further definitions of audit quality, see Dang (2004).

Audit quality is an unobservable variable. As a result, academic researchers use different measures as proxies for audit quality. These include the number of clients; the big $8 / 6 / 5 / 4$ versus non-big 8/6/5/4 and the audit fees (Dang, 2004). To empirically test the current research hypotheses, this paper uses the big four accounting firms as a proxy for high audit quality.

Dang et al. (2004) use value relevance research method as a measure of marketperceived audit quality. They find a positive association between actual audit quality and market-perceived audit quality, i.e., the ability of investors to use current accounting information to value firms' future performance. They conclude that investors' perceived audit quality, measured by the value-relevance of accounting information, can proxy for actual audit quality.

Demand for audit arises from information asymmetry and agency conflicts between corporate managers, outside investors and intermediaries. From an agency theory perspective, Dang (2004) argues that auditing financial statements is an effective monitoring mechanism that provides assurance to stakeholders that financial statements are free of material misstatements. Glosten and Milgrom (1985) argue that increasing the quality of corporate disclosure reduces information asymmetry and protect the interests of the principles, specifically, current and potential investors. Prior studies show that the big accounting firms are more likely to provide higher quality financial statements with more informative disclosures and reduced earnings 
management (Becker et al. 1998; Teoh and Wong, 1993; Krishnan and Schauer, 2000). Therefore, a rich information environment and low information asymmetry should have many desirable consequences. One of these consequences is the increase in investors' ability to anticipate future earnings change.

Prior studies show that the big accounting firms provided higher quality financial statements. Thus, the stock market's ability to anticipate future earnings is expected to be greater for companies with financial statements audited by the big accounting firms. The regression model of Collins et al. (1994) is used to investigate the relationship between audit quality and the ability of investors to anticipate future earnings. Thus, the first hypothesis states:

H1: The degree of investor's ability to anticipate future earnings is greater for companies with financial statements audited by big four accounting firms.

Previous evidence in Hopkins (1996) finds that financial statement classification influences the stock price judgments of a sophisticated financial statement user group (Hopkins, 1996). However, Hayn (1995) finds that the strength of the association between annual stock returns and annual reported earnings changes is considerably lower for unprofitable firms than for profitable firms. The empirical findings in Hayn (1995) suggest that unprofitable firms' current stock returns contain a higher proportion of non-current earnings information. As a result, it is interesting to examine whether audit quality is one source of this non-current earnings information.

Healy and Palepu (2001:406) argue that “.....while theory suggests that auditors enhance the credibility of financial reports, empirical research has provided surprisingly little evidence to substantiate it". Therefore, empirical research is still 
needed to examine the extent to which audit quality increases the credibility of financial reports and hence increases investors' earnings predictability. Earnings predictability is measured by the degree to which investors are able to better anticipate future earnings changes when financial statements are audited by the big four accounting firms.

In a recent paper, Schleicher et al. (2007) provide evidence that the association between corporate disclosure and the investor's ability to anticipate future earnings change is not the same for profitable and unprofitable firms. They find that the ability of stock returns to anticipate next year's earnings change is significantly stronger for high disclosure unprofitable firms. They do not find the same results for profitable firms. Therefore, based on the results in Schleicher et al. (2007), it will be safe to examine the sensitivity of the results by examining the impact of audit quality on earnings predictability for profitable and unprofitable firms. Thus, the second hypothesis states:

H2: The strength of the degree of association between investor's ability to anticipate future earnings and audit quality is not the same for profitable firms and unprofitable firms.

\section{Earnings Predictability}

The present paper uses the Collins et al. (1994) returns-future earnings regression model to measure earnings predictability and to test the research hypothesis. However, only two future earnings growth variables are included in the regression $(N$ $=2$ and $k=1,2)$ rather than three future years. In addition, in defining the earnings growth variable, earnings change is deflated by price and not by lagged earnings. The latter adjustment is made to preserve a maximum number of observations for the analyses (Hussainey et al., 2003). These adjustments yields the following modified model: 


$$
R_{t}=b_{0}+b_{1} X_{t}+\sum_{k=1}^{2} b_{k+1} X_{t+k}+\sum_{k=1}^{2} b_{k+N+1} R_{t+k}+b_{2 N+2} E P_{t-1}+b_{2 N+3} A G_{t}+u_{t}
$$

Where:

$$
\begin{aligned}
& b_{0} \quad: \text { Intercept; } \\
& b_{1}-b_{8}: \text { Coefficient of slope parameters; } \\
& \mu \quad: \text { Error term. } \\
& R_{t} \quad: \text { Stock return for period } t \\
& R_{t+1} \quad: \text { Stock return for period } t+1 \\
& R_{t+2}: \text { Stock return for period } t+2 \\
& X_{t} \quad: \text { Earnings change per share in period } t \text { deflated by the share price four }
\end{aligned}
$$
months after the end of the financial year $t-1$

$X_{t+1}$ : Earnings change per share in period $t+1$ deflated by the share price four months after the end of the financial year $t-1$

$X_{t+2}$ : Earnings change per share in period $t+2$ deflated by the share price four months after the end of the financial year $t-1$

$E P_{t-1}$ : Earnings yield is defined as earnings per share for period $t$ - $l$ divided by share price four months after the end of the financial year $t-1$ $A G_{t}$ : Total assets growth for period $t$

Further, the above model is expanded by including an audit dummy variable (AUDIT) to examine the potential value of audit quality to investors. All right-hand side variables are interacted with this dummy $(1=$ when financial statements are audited by one of the big four accounting firms; 0 otherwise). All explanatory variables in (1) are interacted with the dummy variable, AUDIT. This yields the following regression model that is used to test the research hypotheses:

$$
\begin{aligned}
R_{t}=b_{0}+ & b_{1} X_{t}+\sum_{k=1}^{2} b_{k+1} X_{t+k}+\sum_{k=1}^{2} b_{k+3} R_{t+k}+b_{6} E P_{t-1}+b_{7} A G_{t}+b_{8} A U D I T+b_{9}\left[A U D I T * X_{t}\right] \\
& +\sum_{k=1}^{2} b_{k+9}\left[A U D I T * X_{t+k}\right]+\sum_{k=1}^{2} b_{k+11}\left[A U D I T * R_{t+k}\right]+b_{14}\left[A U D I T * E P_{t-1}\right]+b_{15}\left[A U D I T * A G_{t}\right]+u_{t}
\end{aligned}
$$

Following Lee et al. (2007), the present study seeks to test the hypothesis that audit quality leads to a significant improvement in investors' predictability of future earnings growth. More specifically, if financial statements of a particular firm audited by the big four accounting firms, then this information should be reflected in stock market prices as financial statements are more credible. As a result, one would expect 
that realised future earnings will be partially anticipated by current stock returns. If this is the case, then the coefficient on interacted future earnings, Audit $* X_{t+1}$ and Audit* $X_{t+2}$, will be positive in the returns-earnings regression model (2). In other words, high audit quality enhances the credibility of financial reports and hence helps investors to better predict future earnings changes.

\section{Data}

Lee et al. (2007) provide evidence that the big accounting firms lost their audit quality advantage after 1995 as the relationship between audit quality and the investors' ability to anticipate future earnings was not significant. The present paper covers all UK non-financial firms for firms with financial year ends 1996 to 2002. Therefore, year 1996 is chosen to examine whether the big accounting firms in the UK market lost their audit quality advantage. Schleicher et al. (2007) examine the association between voluntary disclosure and investors' ability to predict future earnings. Their sample size was 4568 firms-years for the period 1996-2002. The present study uses the same sample collected by Schleicher et al. (2007) to examine the effect of audit quality on share price anticipation of earnings. However, the number of firms is reduced further due to missing information about audit type. The number of usable observations used in the present study is 4417 firm-years for the period 1996-2002. This presents a sample of 3736 profitable firms and 681 unprofitable firms.

Datastream is used to collect accounting and return data. Earnings number is defined as operating income before all exceptional items (Worldscope item 01250). Earnings per share is obtained by dividing item 01250 by the outstanding number of shares. Stock returns are calculated as buy-and-hold returns (inclusive of dividends) over a 12-month period from eight months before the financial year-end to four months after 
the financial year-end. Earnings yield, $E P_{t-1}$, is defined as period $t-1$ 's earnings over price four months after the financial year-end of period $t-1 . A G_{t}$ is the growth rate of book value of total assets (Worldscope item 02999) for period $t$. Because audit quality is unobservable, the present study uses the audit type as a proxy for audit quality. Audit type is measured by Worldscope item 07800 which represents the names of the auditor employed by a company to examine its financial statements. Auditor size is used, specifically the big four versus non-big four, to differentiate audit quality levels. The big four accounting firms in the sample are Deloitte \& Touche; Ernst \& Young; KPMG and PricewaterhouseCooper.

\section{Empirical Results}

The effect audit quality on the investors' ability to predict future earnings is examined. Tables 1 and 2 report the results. For the whole sample, consistent with prior studies, Table 1 shows that the coefficient on $X_{t}$ is positive and significant at the 1 percent level. Additionally, there is evidence that investors are able to anticipate future earnings two years ahead for firms with financial statements audited by non-big four accounting firms. The estimate coefficients on $X_{t+1}$ and $X_{t+2}$ are positive and significant at the 1 percent level. The incremental predictive value of audit quality for earnings predictability by investors is given by the estimate coefficients on Audit $* X_{t+1}$ and Audit $* X_{t+2}$. Table 1 shows that these coefficients are positive and highly significant at the 1 percent level. These results indicate that current stock returns incorporate future earnings information much more strongly for companies with financial statements audited by one of the four accounting firms than companies with those with financial statements audited by non-big four auditors. Therefore, hypothesis 1 is supported (not rejected) based on the sample results. 
To test hypothesises 2; the sample is divided into two categories: profitable and unprofitable firms. A regression model is then run for each category. Results are reported in Table 2. The table shows a number of significant differences between profitable and unprofitable firms. In particular, three major differences are found:

First: Table 2 shows a higher earnings response coefficient on the current earnings variable for profitable firms than unprofitable firms. The coefficient on $X_{t}$ is 0.75 with a p-value of 0.001 for profitable firms, while it is insignificantly negative for unprofitable firms $\left(X_{t}=-0.11\right.$ with a p-value of 0.559$)$. These results are consistent with Hayn (1995) and Schleicher et al. (2007) who find that the strength of the relation between annual stock returns and same-period earnings changes is lower for unprofitable firms than for profitable firms.

Second: Table 2 shows that there is no evidence of share price anticipation of earnings for unprofitable firms with financial statements audited by non-big four accounting firms. For these companies, the coefficient estimate on $X_{t+1}$ is 0.03 with a p-value of 0.883 and the coefficient estimate on $X_{t+2}$ is -0.11 with a p-value of 0.401 . These results indicate that investors are not able to predict future earnings for unprofitable firms with financial statements audited by non-big four accounting firms. In contrast there is strong evidence that profitable companies with financial statements audited by non-big four accounting firms do exhibit share price anticipation of earnings for two years ahead. The coefficients estimates on $X_{t+1}$ and $X_{t+2}$ are positive ( 0.84 and 0.17 , respectively) and significant at the one percent level (p-values $=0.001$ and 0.001 , respectively). 
Third: for the effect of audit quality on the investors' ability to predict future earnings, Table 2 shows that the coefficient estimates on Audit* $X_{t+1}$ and Audit $^{*} X_{t+2}$ for unprofitable firms are still insignificant $\left(\right.$ Audit $* X_{t+1}=-0.03$ with a p-value of 0.877 and Audit* $X_{t+2}=0.16$ with a p-value of 0.306). These results indicate that audit quality does not improve the stock market's ability to predict future earnings for unprofitable firms. In contrast there is a significant effect of audit quality on investors' earnings predictability for profitable firms. The coefficient estimates on Audit* $X_{t+1}$ and Audit $^{*} X_{t+2}$ for profitable firms are positive and significant at the one percent level ( Audit $* X_{t+1}=0.57$ with a p-value of 0.001 and Audit $^{*} X_{t+2}=0.21$ with a p-value of 0.001 ).

Overall the evidence for profitable firms suggests that investors are able to anticipate future earnings changes two years ahead, and this ability is improved when financial statements audited by one of the big four accounting firms. On the other hand, the same results were not found for unprofitable firms with financial statements audited by one of the big four accounting firms.

A statistical test to examine the extent to which the association between investors' ability to predict future earnings and audit quality is significantly stronger for profitable firms than unprofitable firms was done. This test was done by including all firms in one dataset and creating a dummy variable to be equal 1 for profitable firms and zero otherwise and interacting the profit dummy variable throughout the model. This analysis shows that the coefficient estimate on profit*Audit* $X_{t+1}$ and profit $^{*}$ Audit $* X_{t+2}$ are positive and significant at the 1 percent level (not reported in the table). This suggests that that the strength of the degree of association between 
investors' ability to anticipate future earnings and audit quality is not the same for profitable firms and unprofitable firms. Therefore, hypothesis 2 is supported (not rejected) based on the sample results.

\section{Insert Table 2 here}

\section{Conclusion}

The Future Earnings Response Coefficient "FERC" framework previously used by Hussainey et al. (2003) and others was used to investigate whether audit quality (financial statements are audited by the big four accounting firms) is positively associated with earnings predictability (the investors' ability to anticipate future earnings). The findings are based on a sample of 4417 companies for the year ends during 1996 to 2002.

Evidence is found that financial statements reveal value relevant information to investors for predicting future earnings. Investors' earnings predictability is increased when companies' financial statements are audited by one of the big four accounting firms. However, these findings are not applicable for unprofitable firms.

The research findings may have important implications for audit quality literature. The findings show that audit size (the big four versus non-big four) is a good proxy for the actual and perceived audit quality. Therefore, firms need to pay attention to who audit their financial statements because this type of information is important to their key stakeholders (i.e. investors and financial analysts) in making their investment decisions. 
Taken together, the paper provides the first direct UK empirical evidence that audit quality improves the investor's ability to anticipate future earnings. Future research may be conducted to examine the potential value of audit quality to other stakeholders. In addition, a large number of studies provide evidence corporate disclosure and a set of corporate governance mechanisms such as ownership structure and board and audit committee composition (e.g., Eng and Mak, 2003). Therefore, it would be interesting to extend the present study by testing the extent to which these mechanisms affect the association between audit quality and investors' ability to predict future earnings.

Similar to Lee et al. (2007); the present study tries to answer a particular research question: Have the big four accounting firms lost their audit quality advantage? Therefore it ignores some variables of interest that would affect the investors' earnings predictability. In particular, the present study includes a number of limitations. First, it ignores the importance of voluntary disclosure as a value-relevant source of information to investors. Second, it ignores the fact that companies might use different communication channels to convey value relevant information for investors (these include interim reports, conference calls and presentation to financial analysts). Finally it ignores the effect of dividend propensity as an effective value relevant signal for investors in predicting future earnings. 


\section{References}

Ball, R. and Brown, P. (1968), "An empirical evaluation of accounting income numbers", Journal of Accounting Research, Vol. 6 No. 2, pp. 159-178.

Beattie, V., McInnes, B. and Fearnley, S. (2001), "The analysis of narratives in annual reports: a multidimensional framework", Financial Reporting and Business Communication Conference, Cardiff Business School, $5^{\text {th }}-6^{\text {th }}$ July.

Beaver, W. H. (1968), "The information content of annual earnings announcements". Journal of Accounting Research, Vol. 6 Supplement, pp. 67-92.

Becker, C. L., DeFond, M. L. and Jiambalvo, J. and Subramanyam, K. R. (1998), "The effect of audit quality on earnings management", Contemporary Accounting Research. Vol. 15 No. 1, pp. 1-21.

Collins, D. W., Kothari, S. P., Shanken, J. and Sloan, R. G. (1994), "Lack of timeliness and noise as explanations for the low contemporaneous return-earnings association", Journal of Accounting and Economics, Vol. 18 No. 3, pp. 289-324.

Dang, L. (2004), Assessing Actual Audit Quality, PhD thesis, Drexel University, Philadelphia, USA.

Dang, L., Brown, K.F. and McCullough, B.D. (2004), "Assessing actual audit quality: a value relevance perspective", Working paper, Oregon State University.

Davidson, R. A. and Neu, D. (1993), "A note on association between audit firm size and audit quality", Contemporary Accounting Research, Vol. 9 No. 2, pp. 479-488.

Diamond, D. W. and Verrecchia, R. E. (1991), "Disclosure, liquidity, and the cost of capital", Journal of Finance, Vol. 46 No. 4, pp. 1325-1359.

Eng, L. L. and Mak, Y. T. (2003), "Corporate governance and voluntary disclosure", Journal of Accounting and Public Policy, Vol. 22 No. 4, pp. 293-376.

Gelb, D. S. and Zarowin, P. (2002), "Corporate disclosure policy and the informativeness of stock prices", Review of Accounting Studies, Vol. 7 No. 1, pp. 3352.

Glosten, L., and Milgrom, P. (1985), "Bid, ask, and transaction prices in a specialist market with heterogeneously informed traders", Journal of Financial Economics, Vol. 26, pp. 71-100

Hayn, C. (1995), "The information content of losses", Journal of Accounting and Economics, Vol. 20 No. 2, pp. 125-53.

Healy, P.M. and Palepu, G. (2001), "Information asymmetry, corporate disclosure and capital markets: a review of the empirical disclosure literature", Journal of Accounting and Economics, Vol. 31 No. 1-3, pp. 405-440. 
Hopkins, P. (1996), "The effect of financial statement classification of hybrid financial instruments on financial analysts' stock price judgements", Journal of Accounting Research, Vol. 34 Supplement, pp. 33-50.

Hussainey, K. (2004). A Study of the Ability of (Partially) Automated Disclosure Scores to Explain the Information Content of Annual Report Narratives for Future Earnings. PhD thesis, Manchester University, UK.

Hussainey, K., Schleicher, T. and Walker, M. (2003), "Undertaking large-scale disclosure studies when AIMR-FAF ratings are not available: the case of prices leading earnings", Accounting and Business Research, Vol. 33 No. 4, pp. 275-294.

Hussainey, K. and Walker, M. (2009), "The effects of voluntary disclosure policy and dividend propensity on prices leading earnings". Accounting and Business Research, forthcoming.

King, R. (1996), "Reputation formation for reliable reporting: an experiment investigation", The Accounting Review, Vol. 71 No. 3, pp. 375-396.

Krishnan, J. and Schauer, P. C. (2000), "The differentiation of quality among auditors: evidence from the not-for-profit sector", Auditing: A Journal of Practice and Theory, Vol. 19 No. 2, pp. 9-26.

Lee, B. B., Cox, S. and Roden, D. (2007), "Have the big accounting firms lost their audit quality advantage: evidence from the returns-earnings relation", Journal of Forensic Accounting, Vol. VIII, 271-286.

Lev, B. (1989), "On the usefulness of earnings: lessons and directions from two decades of empirical research", Journal of Accounting Research, Vol. 27 Supplement, pp. 153-192.

Lundholm, R. J. and Myers, L. A. (2002), "Bringing the future forward: the effect of disclosure on the return-earnings relation", Journal of Accounting Research, Vol. 40 No. 3, pp. 809-839.

Palmrose, Z. (1988), "An analysis of auditor litigation and audit service quality", The Accounting Review, Vol. 64 No. 1, pp. 55-73.

Schleicher, T. (1996). Corporate Financial Disclosure and Share Price Anticipation of Earnings. MPhil Dissertation, Manchester University, Manchester, UK.

Schleicher, T., Hussainey, K. and Walker, M. (2007), "Loss firms' annual report narratives and share price anticipation of earnings", The British Accounting Review, Vol. 39 No. 2, pp. 153-171.

Schleicher, T. and Walker, M. (1999), "Share price anticipation of earnings and management's discussion of operations and financing", Accounting and Business Research, Vol. 29 No. 4, pp. 321-35. 
Teoh, S. H. and Wong, T. J. (1993), "Perceived auditor quality and the earnings response coefficient", The Accounting Review, Vol. 68 No. 2, pp. 346-366.

Titman, S. and Trueman, B. (1986), "Information quality and the valuation of new issues", Journal of Accounting and Economics, Vol. 8 No. 2, pp. 159-172.

Walker, M. (2004). 'Market based accounting research', in C. Clubb ed. Blackwells Encyclopaedia of Management, Volume 1. Blackwell's. 
Table 1: The effect of audit quality on investors' ability to predict future earnings

\begin{tabular}{|c|c|}
\hline $\begin{array}{c}\text { Independent } \\
\text { Variable }\end{array}$ & Full Sample \\
\hline Intercept & $\begin{array}{c}-0.09 * * * \\
(0.001)\end{array}$ \\
\hline$X_{t}$ & $\begin{array}{c}0.64 * * * \\
(0.001) \\
\end{array}$ \\
\hline$X_{t+1}$ & $\begin{array}{c}0.69 * * * \\
(0.001)\end{array}$ \\
\hline$X_{t+2}$ & $\begin{array}{c}0.15^{* * * *} \\
(0.001) \\
\end{array}$ \\
\hline$R_{t+1}$ & $\begin{array}{c}-0.04 * * * \\
(0.009)\end{array}$ \\
\hline$R_{t+2}$ & $\begin{array}{c}-0.04 * * \\
(0.012)\end{array}$ \\
\hline$A G_{t}$ & $\begin{array}{c}0.66^{* * * *} \\
(0.001)\end{array}$ \\
\hline$E P_{t-1}$ & $\begin{array}{l}0.14 * * * \\
(0.001)\end{array}$ \\
\hline Audit & $\begin{array}{c}0.00 \\
(0.999) \\
\end{array}$ \\
\hline Audit $* X_{t}$ & $\begin{array}{l}1.11 * * * * \\
(0.001)\end{array}$ \\
\hline Audit $* X_{t+1}$ & $\begin{array}{l}0.43 * * * \\
(0.001)\end{array}$ \\
\hline Audit $* X_{t+2}$ & $\begin{array}{l}0.14 * * * \\
(0.001)\end{array}$ \\
\hline Audit* $R_{t+1}$ & $\begin{array}{c}0.02 \\
(0.282)\end{array}$ \\
\hline Audit $* R_{t+2}$ & $\begin{array}{c}-0.01 \\
(0.425) \\
\end{array}$ \\
\hline Audit* $E P_{t-1}$ & $\begin{array}{c}0.60 * * * \\
(0.001)\end{array}$ \\
\hline$A u d i t * A G_{t}$ & $\begin{array}{c}-0.13 * * * \\
(0.001)\end{array}$ \\
\hline Observations & 4417 \\
\hline Full model Adj. $\mathrm{R}^{2}$ & 0.102 \\
\hline
\end{tabular}

MODEL:

$$
\begin{aligned}
R_{t}=b_{0}+ & b_{1} X_{t}+\sum_{k=1}^{2} b_{k+1} X_{t+k}+\sum_{k=1}^{2} b_{k+3} R_{t+k}+b_{6} E P_{t-1}+b_{7} A G_{t}+b_{8} A U D I T+b_{9}\left[A U D I T * X_{t}\right] \\
& +\sum_{k=1}^{2} b_{k+9}\left[A U D I T * X_{t+k}\right]+\sum_{k=1}^{2} b_{k+11}\left[A U D I T * R_{t+k}\right]+b_{14}\left[A U D I T * E P_{t-1}\right]+b_{15}\left[A U D I T * A G_{t}\right]+u_{t}
\end{aligned}
$$

where:

$R_{t}, R_{t+1}$ and $R_{t+2}=$ Buy-and-hold returns (inclusive of dividends) over a 12-month period starting four months after the end of the previous financial year.

$X_{t}, X_{t+1}$ and $X_{t+2}=$ Earnings change deflated by price. Both current and future earnings changes are deflated by price at the start of the return window for period $t$. Earnings measure is the Worldscope item 01250 
which is operating income before all exceptional items. $E P_{t-1}=$ Period $t-1$ 's earnings over price four months after the financial year-end of period $t-1$.

$A G_{t}=$ The growth rate of total book value of assets for period $t$ (Worldscope item 02999).

Audit $=1$ for companies when their financial statements audited by one of the four big accounting firms; 0 otherwise.

The significance levels (two-tail test): $*=10$ percent, $* *=5$ percent, $* * *=1$ percent.

$\mathrm{P}$-values are reported in parentheses. 
Table 2: The effect of audit quality on investors' ability to predict future earnings: Profitable firms versus unprofitable firms

\begin{tabular}{|c|c|c|}
\hline $\begin{array}{l}\text { Independent } \\
\text { Variable }\end{array}$ & Profitable firms & Unprofitable firms \\
\hline Intercept & $\begin{array}{l}-0.03^{*} \\
(0.094)\end{array}$ & $\begin{array}{c}-0.28 * * * \\
(0.001)\end{array}$ \\
\hline$X_{t}$ & $\begin{array}{c}0.75 * * * \\
(0.001)\end{array}$ & $\begin{array}{c}-0.11 \\
(0.559)\end{array}$ \\
\hline$X_{t+1}$ & $\begin{array}{l}0.84 * * * \\
(0.001)\end{array}$ & $\begin{array}{c}0.03 \\
(0.883)\end{array}$ \\
\hline$X_{t+2}$ & $\begin{array}{c}0.17 * * * \\
(0.001) \\
\end{array}$ & $\begin{array}{c}-0.11 \\
(0.401)\end{array}$ \\
\hline$R_{t+1}$ & $\begin{array}{l}-0.04^{*} \\
(0.082)\end{array}$ & $\begin{array}{c}-0.03 \\
(0.113)\end{array}$ \\
\hline$R_{t+2}$ & $\begin{array}{c}-0.03 \\
(0.249)\end{array}$ & $\begin{array}{c}-0.03 \\
(0.179)\end{array}$ \\
\hline$A G_{t}$ & $\begin{array}{l}0.52 * * * \\
(0.001)\end{array}$ & $\begin{array}{c}-0.12 \\
(0.546)\end{array}$ \\
\hline$E P_{t-1}$ & $\begin{array}{c}0.13 * * * \\
(0.001)\end{array}$ & $\begin{array}{l}0.09 * * * \\
(0.001)\end{array}$ \\
\hline Audit & $\begin{array}{c}-0.07 * * * \\
(0.001)\end{array}$ & $\begin{array}{c}0.07 \\
(0.165) \\
\end{array}$ \\
\hline Audit $* X_{t}$ & $\begin{array}{l}1.72 * * * \\
(0.001)\end{array}$ & $\begin{array}{c}0.23 \\
(0.270)\end{array}$ \\
\hline Audit $* X_{t+1}$ & $\begin{array}{l}0.57 * * * \\
(0.001)\end{array}$ & $\begin{array}{c}-0.03 \\
(0.877)\end{array}$ \\
\hline Audit $* X_{t+2}$ & $\begin{array}{l}0.21 * * * \\
(0.001)\end{array}$ & $\begin{array}{c}0.16 \\
(0.306)\end{array}$ \\
\hline Audit $* R_{t+1}$ & $\begin{array}{c}0.01 \\
(0.770)\end{array}$ & $\begin{array}{c}0.02 \\
(0.419)\end{array}$ \\
\hline Audit $* R_{t+2}$ & $\begin{array}{l}-0.04^{*} \\
(0.090) \\
\end{array}$ & $\begin{array}{c}-0.01 \\
(0.955)\end{array}$ \\
\hline Audit $* E P_{t-1}$ & $\begin{array}{l}0.87 * * * \\
(0.001)\end{array}$ & $\begin{array}{c}0.12 \\
(0.559)\end{array}$ \\
\hline$A u d i t * A G_{t}$ & $\begin{array}{c}-0.12 \\
(0.001)\end{array}$ & $\begin{array}{c}-0.10 * * * \\
(0.001)\end{array}$ \\
\hline Observations & 3736 & 681 \\
\hline Full model Adj. $\mathrm{R}^{2}$ & 0.113 & 0.022 \\
\hline
\end{tabular}

MODEL:

$$
\begin{aligned}
R_{t}=b_{0}+ & b_{1} X_{t}+\sum_{k=1}^{2} b_{k+1} X_{t+k}+\sum_{k=1}^{2} b_{k+3} R_{t+k}+b_{6} E P_{t-1}+b_{7} A G_{t}+b_{8} A U D I T+b_{9}\left[\text { AUDIT } * X_{t}\right] \\
& +\sum_{k=1}^{2} b_{k+9}\left[\text { AUDIT } * X_{t+k}\right]+\sum_{k=1}^{2} b_{k+11}\left[\text { AUDIT } * R_{t+k}\right]+b_{14}\left[\text { AUDIT } * E P_{t-1}\right]+b_{15}\left[\text { AUDIT } * A G_{t}\right]+u_{t}
\end{aligned}
$$

where:

$R_{t}, R_{t+1}$ and $R_{t+2}=$ Buy-and-hold returns (inclusive of dividends) over a 12-month period starting four months after the end of the previous financial year. 
$X_{t}, X_{t+1}$ and $X_{t+2}=$ Earnings change deflated by price. Both current and future earnings changes are deflated by price at the start of the return window for period $t$. Earnings measure is the Worldscope item 01250 which is operating income before all exceptional items. $E P_{t-1}=$ Period $t-1$ 's earnings over price four months after the financial year-end of period $t-1$.

$A G_{t}=$ The growth rate of total book value of assets for period $t$ (Worldscope item 02999).

Audit $=1$ for companies when their financial statements audited by one of the four big accounting firms; 0 otherwise.

The significance levels (two-tail test): $*=10$ percent, $* *=5$ percent, $* * *=1$ percent.

$\mathrm{P}$-values are reported in parentheses. 